\title{
Expression of Cell Cycle-related Proteins p16, p27 and Ki-67 Proliferating Marker in Laryngeal Squamous Cell Carcinomas and in Laryngeal Papillomas
}

\author{
URSZULA CIESIELSKA ${ }^{1}$, TOMASZ ZATONSKI ${ }^{2}$, KATARZYNA NOWINSKA $^{1}$, \\ KATARZYNA RATAJCZAK-WIELGOMAS ${ }^{1}$, JEDRZEJ GRZEGRZOLKA ${ }^{1}$, \\ ALEKSANDRA PIOTROWSKA ${ }^{1}$, MATEUSZ OLBROMSKI ${ }^{1}$, \\ BARTOSZ PULA ${ }^{1}$, MARZENNA PODHORSKA-OKOLOW ${ }^{1}$ and PIOTR DZIEGIEL ${ }^{1,3}$ \\ Departments of ${ }^{1}$ Histology and Embryology and ${ }^{2}$ Otolaryngology, \\ Head and Neck Surgery, Wroclaw Medical University, Wroclaw, Poland; \\ ${ }^{3}$ Department of Physiotherapy, University School of Physical Education, Wroclaw, Poland
}

\begin{abstract}
Background: The deregulation of the cell cycle is crucial for the processes of carcinogenesis and tumor progression. The cell cycle is under the control of cyclindependent kinases (CDKs) and their inhibitors (CDKIs). Proteins p16 and p27 are CDKIs, and their altered expression has been noticed in many types of cancers. The aim of this study has been to compare the expression levels of these proteins in laryngeal papillomas and carcinomas in order to confirm their predictive value in cancer development. Materials and Methods: Eighty-three cases of laryngeal lesions were analyzed: cancers (51) and papillomas (32). Immunohistochemical (IHC) reactions were performed in order to detect the expression levels of p16, p27 and Ki-67. Immunofluorescence (IF) and western blot were performed on HEp-2 cell line. Results: The expression of p16 and p27 was decreased in cancer cells in comparison to papillomas. Additionally, we observed cytoplasmic expression of 16 in cancers and lack of such expression in papillomas. The same pattern of expression of p16 was also detected by IF and western blot analysis in HEp-2 cell line. The expression of Ki-67 protein revealed no significant differences in the case of papilloma compared with cancer, however a significant correlation between tumor grade and the nuclear expression of Ki-67 was observed. Conclusion: There is a necessity in finding biomarkers, which would predict the risk level of malignant transformation. Our study
\end{abstract}

Correspondence to: Urszula Ciesielska, Ph.D., Department of Histology and Embryology, Wroclaw Medical University, Chalubinskiego 6a, 50-368 Wroclaw, Poland. Tel: +48 717841368, Fax: +48 717840082, e-mail: urszula.ciesielska@umed.wroc.pl

Key Words: Laryngeal Squamous Cell Carcinoma, Papilloma, p16, p27. has confirmed that altered expressions of the p16 and p27 proteins might be useful biomarkers in the progression of laryngeal squamous cell carcinomas (LSCC).

Laryngeal carcinomas are very common head and neck tumors, which are increasing in prevalence worldwide. The most abundant histological type is squamous cell carcinoma (SCC) with predominantly diagnosed laryngeal localization (1-4). The neoplastic transformation of the cells consists of many phases associated with multiple changes in cell genome often induced by exogenous factors, i.e. viral infections (e.g. human papillomas virus-HPV). All these factors influence the action of molecular regulatory pathways through the deactivation of tumor suppressor genes and the activation of oncogenes. They can be inactivated or overexpressed due to mutations, loss of heterozygosity, deletions or epigenetic modifications, such as methylation $(1,2)$. The disruption of the proper function of the suppressor genes results in the deregulation of cell cycle, uncontrolled cell proliferation, and eventually cancer development (5).

The regulation of the cell cycle is essential for a cell to progress through it. The process of regulation takes place in at least two main checkpoints, on the border of $\mathrm{G}_{1} / \mathrm{S}$, and $\mathrm{G}_{2} / \mathrm{M}$ phases, due to the interaction between activator and suppressor proteins. Abnormalities in the regulation of the cell cycle can lead to carcinogenesis.

Cell cycle progression is under the control of the regulatory proteins: cyclins and their cofactors cyclindependent kinases (CDKs), which are upregulated by cyclins and down regulated by CDK inhibitors (CDKIs). Protein p16 and $\mathrm{p} 27$ are cyclin-dependent kinase inhibitors. They belong to two different groups - Cip/Kip (p21, p27, p57) inhibiting cyclin A/E-cdk2, and INK4 (p16, p18, p19), which inhibits CDK4 and CDK6 $(2,6)$. 
The p16 protein is an important inhibitor of CDKIs, as well as a suppressor of the tumor development, and the loss of its function may lead to neoplastic transformation $(7,8)$. In proper cell cycle, p16 inhibits cell cycle progression by preventing the $\mathrm{Rb}$ protein from being phosphorylated $(7,8)$. In normal cells, the expression of p16 takes place only in the nucleus, in the parabasal layers of epithelium; whilst in SCCs it occurs in all layers. In the latter case the expression is noticed predominantly in the nucleus, but also in the cytoplasm of tumor cells $(5,9,10)$.

The etiology of alterations of p16 expression in head and neck squamous cell carcinomas (HNSCC) may be caused by two important factors, smoking and HPV infection. In patients with HPV infection, nuclear expression of this protein is noticed. However, in cases where p16 function was disrupted by mutation or other genetic alterations, moderate or increased cytoplasmic expression of p16 could be observed $(11,12)$.

The p27 protein also acts as a CDKI, which restrains $\mathrm{CDK} /$ cyclin complexes, resulting in cell cycle arrest in the $\mathrm{G}_{1}$ phase. Interestingly, p27 can also inhibit the cell cycle directly without other cofactors, such as cyclin D or CDK4/6 (2). In normal cells, p27 expression is noticed in the nucleus, whilst in tumor cells, expression loss is observed $(8,13)$. Although mutations of the $p 27$ gene are rare in human cancer, a decreased expression of p27 in the nucleus of cancer cells has been associated with poor prognosis and reduced patient survival in many types of cancers, including $\operatorname{HNSCC}(8,13,14)$.

As inhibitory proteins, p16 and p27 play an important role in the prevention of neoplastic transformations of cells. In different ways they stop the progression of the cell cycle, and they both cause cell cycle arrest to repair DNA damages. They exhibit decreased or increased levels of expression and different nuclear or cytoplasmic localization in many types of malignant neoplasms, e.g. head and neck, urinary bladder, lung cancer and brain tumors $(8,15)$. The aim of this study was to investigate the differences in expression of cell cycle regulatory proteins p16 and p27 in LSCC and papillomas of the larynx in order to understand the pathogenesis of these lesions.

\section{Materials and Methods}

Tissue samples (patients). Eighty-three formalin-fixed, paraffinembedded blocks containing tissue samples of laryngeal cancers $(n=51)$ and laryngeal papillomas $(n=32)$ were obtained from patients treated at the Department of Otolaryngology, Head and Neck Surgery, Wroclaw Medical University, Poland.

The study population of the papilloma cases included 12 women and 20 men. The average age of the study group was 40.28 years. The study population of carcinoma cases included 9 women and 42 men. The average age of the study group was 60.22 years. The grade of malignancy $(\mathrm{G})$ was determined on TNM (tumor size,
Table I. Patients' clinicopathological characteristics.

\begin{tabular}{|c|c|c|c|c|}
\hline & \multicolumn{2}{|c|}{ Papilloma $(n=32)$} & \multicolumn{2}{|c|}{ Carcinoma $(n=51)$} \\
\hline $\begin{array}{l}\text { Mean age } \pm S D \\
\text { (range) }\end{array}$ & \multicolumn{2}{|c|}{$\begin{array}{c}40,28 \pm 19,18 \\
(4-84)\end{array}$} & \multicolumn{2}{|c|}{$\begin{array}{c}60.22 \pm 8.47 \\
(44-74)\end{array}$} \\
\hline Parameters & $\mathrm{N}$ & $\%$ & $\mathrm{~N}$ & $\%$ \\
\hline \multicolumn{5}{|l|}{ Gender } \\
\hline Male & 20 & 62.5 & 42 & 82.35 \\
\hline Female & 12 & 37.5 & 9 & 17.65 \\
\hline \multicolumn{5}{|l|}{ Tumor size } \\
\hline $\mathrm{T} 1$ & & & 0 & 00.00 \\
\hline $\mathrm{T} 2$ & & & 7 & 13.73 \\
\hline $\mathrm{T} 3$ & & & 26 & 50.98 \\
\hline $\mathrm{T} 4$ & & & 18 & 35.29 \\
\hline \multicolumn{5}{|l|}{ Lymph nodes } \\
\hline NO & & & 29 & 56.86 \\
\hline $\mathrm{N} 1, \mathrm{~N} 2, \mathrm{~N} 3$ & & & 22 & 43.14 \\
\hline \multicolumn{5}{|l|}{ Grade } \\
\hline G1 & & & 11 & 21.57 \\
\hline $\mathrm{G} 2$ & & & 27 & 52.94 \\
\hline G3 & & & 13 & 25.49 \\
\hline \multicolumn{5}{|l|}{ pTNM } \\
\hline I & & & 0 & 00.00 \\
\hline II & & & 4 & 07.84 \\
\hline III & & & 25 & 49.02 \\
\hline IV & & & 22 & 43.14 \\
\hline \multicolumn{5}{|l|}{ Stage } \\
\hline Early & & & 4 & 07.84 \\
\hline Advanced & & & 47 & 92.16 \\
\hline
\end{tabular}

lymph nodes, metastases) classification of malignant tumors. Clinical and pathological characteristics of patients are presented in Table I.

Immunohistochemistry (IHC). In each case, haematoxylin and eosin (HE) staining was performed for verification of histopathological diagnosis. For HE staining, 7- $\mu \mathrm{m}$-thick sections were prepared (microtome RM 2145; Leica Biosystems, Nussloch, Germany). For IHC reaction, $4-\mu \mathrm{m}$-thick sections were placed onto Superfrost Plus slides (Menzel Gläser, Braunschweig, Germany). Deparaffinization, hydration and heat-induced epitope uncovering were carried out according to the 3-in-1 procedure by boiling for 20 minutes at $97^{\circ} \mathrm{C}$ in a Dako PT Link (Dako, Glostrup, Denmark) device, in high or low pH Target Retrieval Solution (Dako). Endogenous peroxidase activity was blocked with the use of Peroxidase-Blocking Solution (Dako). For the evaluation of the antigens' expression levels, specific mouse monoclonal antibodies directed against p16 INK4A (clone G175-405, 1:50+linker; BD Pharmingen, Franklin Lakes, New Jersey, USA), p27KIP1 (clone SX53G8, 1:25; Dako) and Ki-67 (clone MIB-1, 1:100; Dako) were used. The antibodies were diluted in the background-reducing reagent Antibody Diluent (Dako). Incubation was carried out for $1 \mathrm{~h}$ at room temperature with the use of an Autostainer Link 48 (Dako) automated staining platform and the EnVision $^{\mathrm{TM}}$ FLEX Reagents visualization system (Dako). Antigen location sites were visualized by DAB (3, 3'-diaminobenzidine 
Table II. Estimate dprotein expression levels of p16, p27 and Ki-67 in laryngeal papillomas and cancer cells.

\begin{tabular}{lc}
\hline Degree of expression & Percentage of cells with positive IHC reaction \\
\hline $0:$ & $0 \%$ (Lack of expression) \\
$1:$ & $1 \%-10 \%$ \\
$2:$ & $11 \%-25 \%$ \\
$3:$ & $26 \%-50 \%$ \\
$4:$ & $\geq 51 \%$ \\
\hline
\end{tabular}

IHC, Immunohistochemistry.

tetrahydrochloride) staining. The negative control used was an IHC reaction without the use of the primary antibody. The expression of the tested proteins was analyzed by two independent investigators at magnification of $\times 200$ with the use of a BX41 (Olympus, Tokyo, Japan) light microscope coupled with a DP-12 camera and Cell ${ }^{\mathrm{D}}$ (Olympus) software for computer image analysis. The intensity of the expression of p16, p27 and Ki-67 was determined by using a five-point evaluation scale (score 0 to 4 ), taking into account the percentage of cells with a positive IHC reaction relative to all cancer or papilloma cells in a given specimen (Table II). For the evaluation of the cytoplasmic expression of p16, semiquantitative immunoreactive score, IRS - method according to Remmele and Stegner was used, shown in Table III (16). The scale is based on the estimation of the percentage of cancer cells with positive reaction in relation to all cancer cells in the whole tissue section and the intensity of color reaction.

Cell lines. In order to conduct western blot and immunofluorescence experiments, Larynx Epidermoid Carcinoma HEp-2 reference adherent cell line was cultured (the cell line was obtained from the Ludvik Hirszfeld Institute of Immunology and Experimental Therapy, Polish Academy of Sciences, Wroclaw, Poland).

Immunofluorescence $(I F)$. In order to perform IF reactions on HEp2 cells, 24-hour micro-cultures were set up on 8 wells slides covered with Teflon (Roth, Karlsruhe, Germany). The cells were trypsinized, centrifuged and resuspended in $5 \mathrm{ml}$ of medium. A $50 \mu \mathrm{l}$ of $2.5 \times 10^{3}$ cells $/ \mathrm{ml}$ suspension was transferred to the wells on slides, which were placed in an incubator on Petri dishes at $37^{\circ} \mathrm{C}$ for 24 hours. The medium was removed after the incubation and the wells were washed with PBS. Subsequently, the cells were fixed in wells with the use of $4 \%$ formaldehyde in PBS for 12 minutes at room temperature. Cell membrane permeabilization was performed with $0.2 \%$ Triton in PBS for 10 minutes at room temperature. Specific primary mouse monoclonal antibodies were used for the reaction: p16INK4A (clone G175-405, 1:50+linker; BD Pharmingen), p27KIP1 (clone SX53G8, 1:25; Dako). Overnight incubation with primary antibodies was carried out at $4^{\circ} \mathrm{C}$. The preparations were then incubated for $1 \mathrm{~h}$ with donkey anti-mouse secondary Alexa Fluor 488 conjugated antibody (Invitrogen, Waltham, Massachusetts, USA) diluted 1:2000 in the reagent with background-reducing component (antibody diluent, Dako). Preparations were mounted using Prolong Gold Mounting Medium (Invitrogen), which contains DAPI for cellular DNA visualization. Observations were made at $\times 200$ magnification with the use of a BX51 microscope (Olympus) coupled with Cell ${ }^{\mathrm{F}}$ software (Olympus).
Table III. Scale assessing the level of p16 expression in LSCC and papillomas of the larynx (according to Remmele and Stegner, 1987).

\begin{tabular}{lccc}
\hline Points & $\begin{array}{c}\text { Percentage of } \\
\text { cells with } \\
\text { positive reaction }\end{array}$ & Points & $\begin{array}{c}\text { Intensity of the } \\
\text { color reaction }\end{array}$ \\
\hline 0 & $0 \%$ & 0 & No \\
1 & $1 \%-10 \%$ & 1 & Poor \\
2 & $11 \%-50 \%$ & 2 & Average \\
3 & $51 \%-80 \%$ & 3 & Strong \\
4 & $>80 \%$ & & \\
\hline
\end{tabular}

LSCC, Laryngeal squamous cell carcinomas.

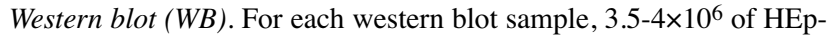
2 cells in the exponential growth phase were taken. The nuclear and cytoplasmic fractions of the studied cell line were isolated with the use of the NE-PER Extraction Kit (Thermo Fisher, Waltham, Massachusetts, USA) according to the manufacturers' instructions. To determine the concentration of protein sex tracted, the BCA protein assay was used (Thermo-Pierce, Waltham, Massachusetts, USA). The cellular extracts were mixed with GLB sample buffer (250 mM TRIS pH 6.8, 40\% glycerol, 20\% $\beta$-mercaptoethanol, 100 $\mathrm{mM}$ DTT, $0.33 \mathrm{mg} / \mathrm{mL}$ bromophenol blue, $8 \%$ SDS) and then denatured for $10 \mathrm{~min}$ at $95^{\circ} \mathrm{C}$. Equal amounts of proteins from cells were loaded into a gel $(30 \mu \mathrm{g} / \mathrm{lane})$ and separated by means of electrophoresis in $7.5 \%$ polyacrylamide gel with SDS in a Mini Protean 3 (Bio-Rad, Hercules, California, USA) apparatus. The proteins were the electrophoretically transferred onto a PVDF Immobilon P (Millipore, Billerica, MA, USA) membrane, which was blocked with milk solution in TBS with $0.1 \%$ Tween 20 (TBST) for non-specific binding sites. The expression levels of the proteins were determined using specific mouse monoclonal anti-human antibodies: p16 INK4A (clone G175-405, 1:50+linker; BD Pharmingen) and p27KIP1 (clone SX53G8, 1:25; Dako). Incubation was conducted overnight at $4^{\circ} \mathrm{C}$ with mild shaking. The membrane was washed three times using $0.2 \%$ TBST buffer. Subsequently, it was incubated in the solution of donkey anti-mouse antibody conjugated with horseradish peroxidase (1:3000, Jackson Immuno Research Laboratories, West Grove, PA, USA). The detection was performed with the use of chemiluminescence substrate from Luminata Crescendo Western HRP (Millipore). The data were collected in a Chemi-Doc XRS Molecular Imager (Bio-Rad) apparatus. The quantifications of cytoplasmic proteins were based on calpain expression, which was determined with the use of rabbit anti-human calpain polyclonal antibody (1:500, Protein Tech, Chicago, IL, USA). The quantification of nuclear proteins was based on histone $\mathrm{H} 3$ expression, determined with the use of rabbit polyclonal antihistone H3 antibodies (1:1000, Cell Signaling, Beverly, MA, USA). The purity of the nuclear and cytoplasmic fractions were manifested by the absence of binding of the anti-calpain antibody to the nuclear proteins and of the anti-histone $\mathrm{H} 3$ antibody to the cytoplasmic proteins. The optical density of the protein bands was measured with the use of the Quantity One (Bio-Rad) software.

Statistical analysis. The Kolmogorov-Smirnov test was used in order to evaluate the normality assumption of the examined groups. 

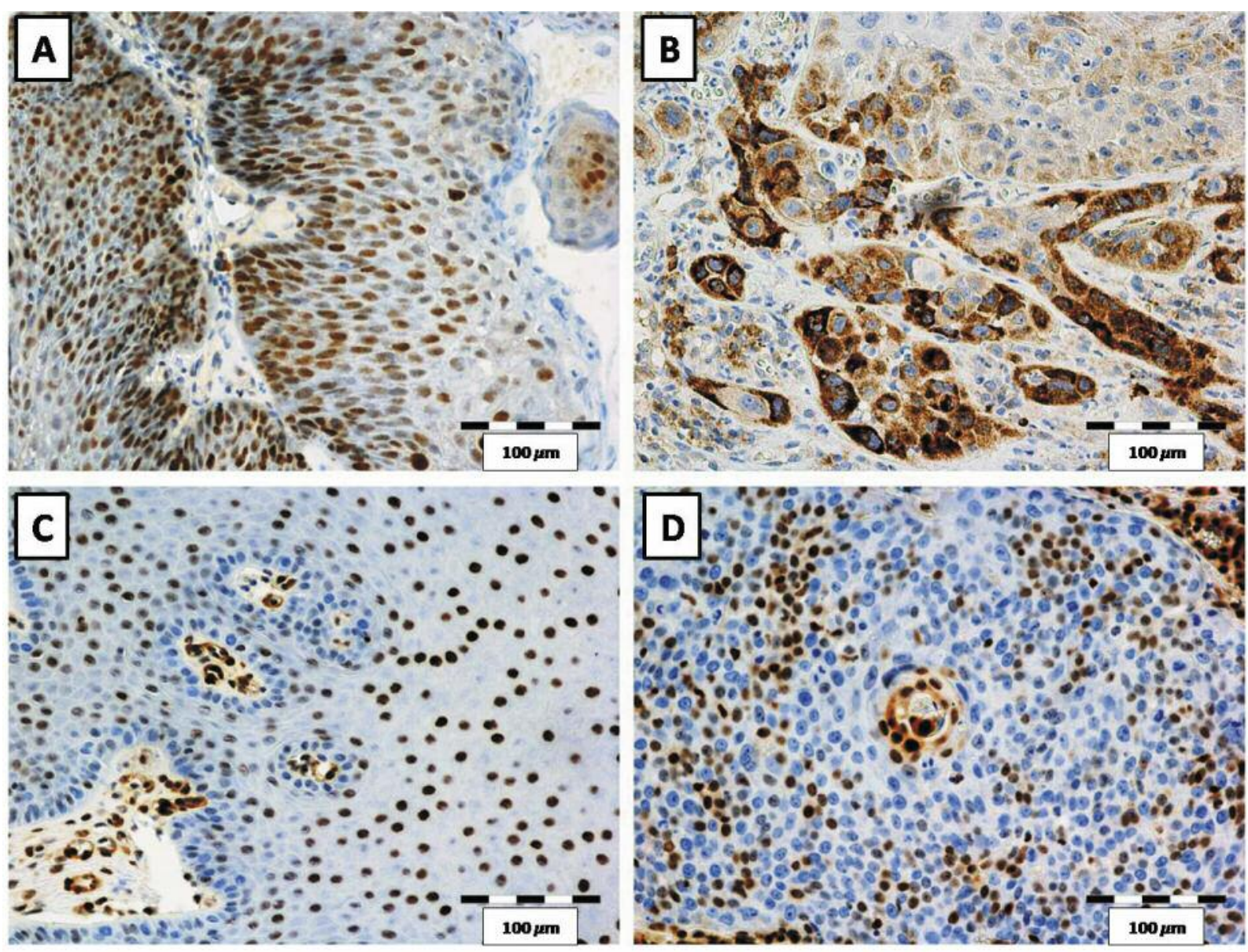

Figure 1. Nuclear expression of p16 (A) and p27 (C) in papilloma cells. Nuclear and cytoplasmic expression of p16 in cancer cells (B). Nuclear expression of 227 in cancer cells (D). Magnification $\times 200$.

Table IV. Degree of nuclear expression of p16, p27 and Ki-67 in cancer and papilloma cells.

\begin{tabular}{|c|c|c|c|c|c|c|}
\hline \multirow[b]{2}{*}{ Degree of expression } & \multicolumn{3}{|c|}{ Cancer $(n=51)$} & \multicolumn{3}{|c|}{ Papilloma $(n=32)$} \\
\hline & $\begin{array}{c}\mathrm{p} 16 \\
(\text { No }(\%))\end{array}$ & $\begin{array}{c}\text { p27 } \\
\text { (No }(\%))\end{array}$ & $\begin{array}{c}\mathrm{Ki}-67 \\
(\text { No }(\%))\end{array}$ & $\begin{array}{c}\mathrm{p} 16 \\
(\text { No }(\%))\end{array}$ & $\begin{array}{c}\text { p27 } \\
(\text { No }(\%))\end{array}$ & $\begin{array}{c}\mathrm{Ki}-67 \\
(\mathrm{No}(\%))\end{array}$ \\
\hline 0 : Lack of expression & $47(92.1)$ & $1(2)$ & 0 & $2(6.2)$ & $1(3.1)$ & 0 \\
\hline $1: 1-10 \%$ of cells & $3(5.9)$ & $10(19,6)$ & $14(27.5)$ & $7(21.9)$ & $1(3.1)$ & $6(18.7)$ \\
\hline 2: $11-25 \%$ & 0 & $17(33.3)$ & $15(29.3)$ & $4(12.5)$ & 0 & $8(25.0)$ \\
\hline $3: 26-50 \%$ & $1(2)$ & $9(17.6)$ & $14(27.5)$ & $5(15.5)$ & $10(31.3)$ & $15(46.9)$ \\
\hline $4: \geq 51 \%$ & 0 & $14(27.5)$ & $8(15.7)$ & $14(43.8)$ & $20(62.5)$ & $3(9.4)$ \\
\hline
\end{tabular}

The comparison of the differences between the examined protein expressions in all the patient groups and the clinicopathological data were prepared with the use of the Mann Whitney test. Additionally, the Spearman correlation test was performed in order to analyze the correlation of the data sets. The Kaplan Meyer method was used to construct survival curves. To evaluate the analysis of survival rate, the Mantel Cox test was performed. All statistical analyses were performed using Prism 5.0 (GraphPad, La Jolla, California, USA). The results were considered statistically significant when $p<0.05$. 
A

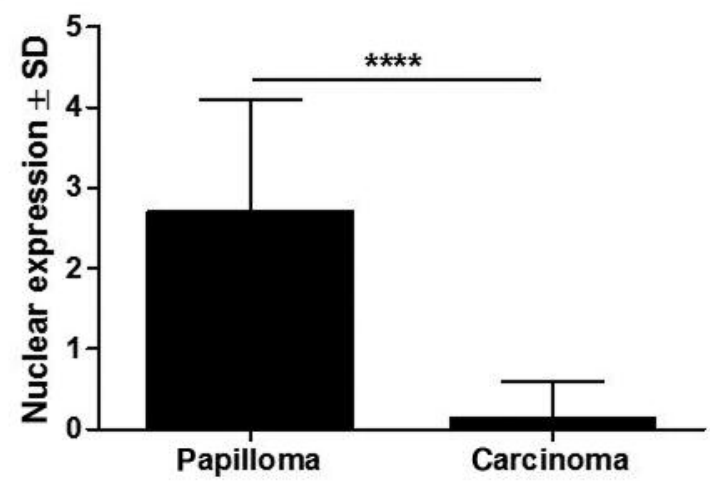

B
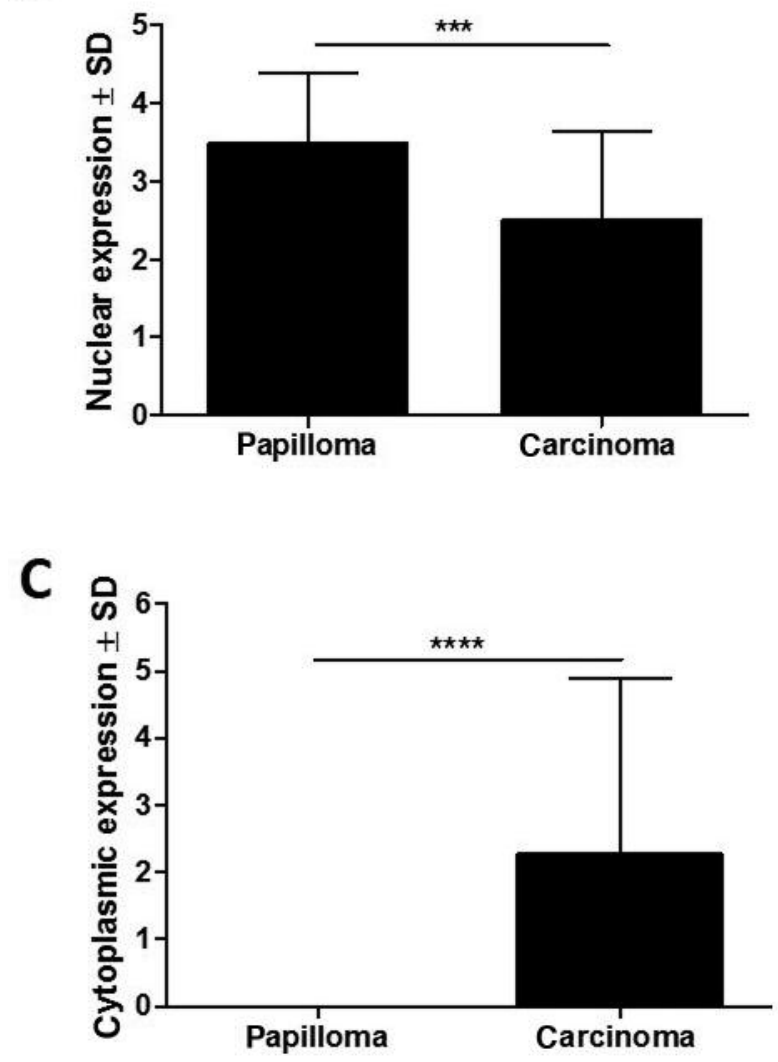

Figure 2. Nuclear expression of p16 (A) and p27 (B) in papillomas and cancer cells. Cytoplasmic expression of p16 in cancer cells $(C)$. Data presented as mean \pm standard deviation (SD). **** $p=0.001$, ****p<0.0001. Mann-Whitney test.

\section{Results}

Expression of the cell cycle-related proteins p16 and p27 were localized in the nuclei of epithelial papillomas and cancer cells (Figure 1, Table IV). Additionally, in the case of

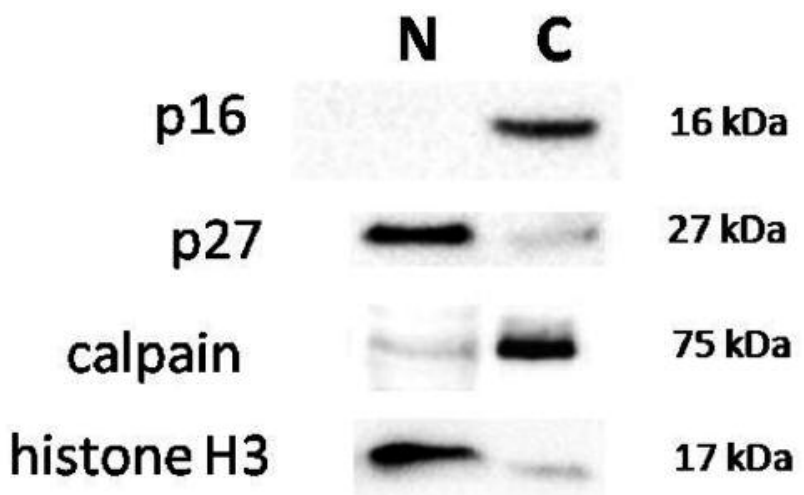

Figure 3. Western blot analysis of nuclear $(N)$ and cytoplasmic $(C)$ expression of p16 and p27 in the HEp-2 cell line (A). Histone H3 and calpain served as internal controls, for nuclear and cytoplasmic proteins, respectively.

cancer cells, we also observed cytoplasmic expression of the p16 protein (Figure 1, Table IV).

The nuclear expression of p16 was detected in 30/32 of laryngeal papillomas and only in 4/51 cases of cancers (Table IV). In addition, weak nuclear and strong cytoplasmic expressions of p16 were detected in cancer cells (Figure 1B). Nuclear expression of p27 was also observed in 50/51 cases of cancer and in 31/32 cases of papilloma (Table III). The statistical analysis revealed that the expression of both analyzed proteins was significantly stronger in papillomas in comparison to cancer cells ( $p=0.001$ for both) (Figure 2, Mann-Whitney test). Moreover, we did not notice cytoplasmic expression of p16 in papilloma cells, but only in cancer cells (Figure 1). On the contrary, in the case of p27 only nuclear expression was observed, in both papilloma and laryngeal cancer cells, although the expression was significantly lower in the latter ones (Figures 1,2).

With the use of specific antibodies, WB analysis revealed the presence of p16 in the cytoplasm of the laryngeal cancer HEp-2 cell line (Figure 3 ). In the case of p27, it was only detected in the nucleus of the HEp-2 cell line (Figure 3). In addition, IF reaction was performed in order to visualize the localization of p16 and p27 in the cell in the nucleus or/and cytoplasm of the p16 and p27 proteins. IF confirmed the cytoplasmic expression of p16 and the nuclear expression of p27 protein in HEp-2 cell line (Figure 4).

In addition, the immunohistochemical expression of Ki-67 was also investigated. A significant correlation between tumor grade and the nuclear expression of Ki-67 was observed. The expression of this protein was significantly higher in G2 and G3, and there were significant differences between G2 vs. G3 ( $p=0.0062)$ and G1 vs. G3 $(p=0.0019)$ (Figure 5A). However, there were no statistically significant differences in the expression of this protein between 

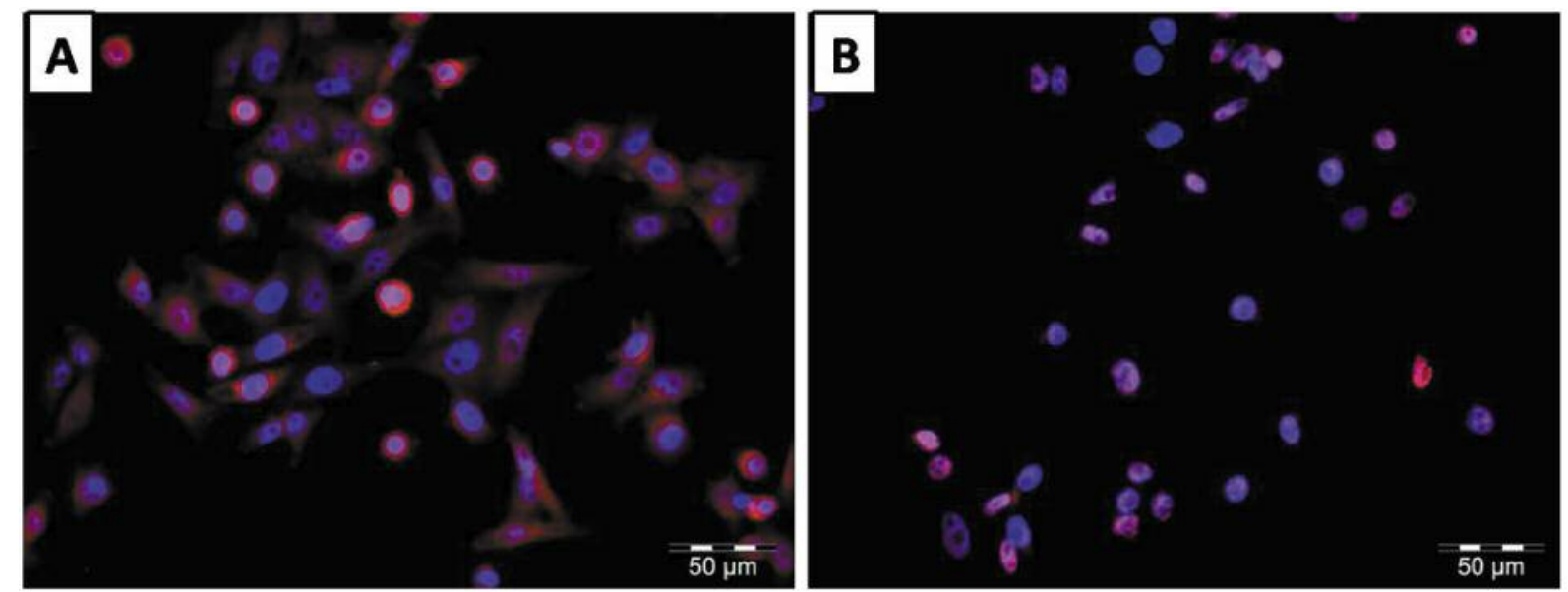

Figure 4. Immunofluorescence reaction showing cytoplasmic expression of p16 (A) and the nuclear expression of p27 (B) in HEp-2 cell line. Magnification $\times 400$.

papilloma and cancer cases. Moreover, we also noticed similar associations in cytoplasmic expression of p16 in cancer cells, which increased within the tumor grade (G2 vs. G3 $p=0.053$, G1 vs. G3 $p=0.0346$; Figure 5B). Additionally, a moderate positive correlation was revealed between $\mathrm{Ki}-67$ nuclear expression and $\mathrm{p} 16$ cytoplasmic expression in cancer cells $(r=0.34, p=0.05$; Figure 6$)$.

Statistical analysis revealed no significant correlation between the survival rate and the expression of all aforementioned proteins.

\section{Discussion}

Despite the fact that the association between HPV infection and benign as well malignant lesions of the upper respiratory tract has been already well documented, there are still ambiguities of the pathways leading to the malignant transformation of the cells $(8,17-19)$.

The p16 and p27 proteins are CDKIs essential in controlling cell cycle progression. The function of p16 is to inactivate CDKs - D1, CDK4 and CDK6, which control the $\mathrm{G}_{1} / \mathrm{S}$ checkpoint, and to reduce the rate of cell growth during the cell cycle. The loss of p16 activity results in an increased transition in the $\mathrm{G}_{1} / \mathrm{S}$ phase (20). It has been suggested that in HNSCC the most common reason of p16 inactivation is due to point mutation or homologous deletion of the gene followed by its hypermethylation (20-22). The level of p16 expression also changes because of the inactivation of $\mathrm{pRb}$. A decreased level of p16 expression is often noticed in different types of HNSCC $(8,23)$. Better knowledge of the altered expression of p16 and its significance in pathogenesis of HNSCC could contribute to the understanding of this process. In this study, a significantly higher nuclear expression of p16 has been observed in papillomas in comparison to cancers. Our findings were in concordance with previous observations of the p16 nuclear expression in many types of head and neck cancers $(12,23,24)$. Additionally, some reports revealed that reduced or even lack of p16 expression correlates with a poor prognosis $(12,21$, $25,26)$. It has also been stated that a negative status of $\mathrm{p} 16$ could be related to more aggressive pathological conditions, probably because of its crucial role in the regulation of the cell proliferation (20). Contrary to these findings, we did not observe significant correlations between p16 expression and survival. Interestingly, we noticed strong cytoplasmic expression of p16 in cancer cells and lack of such expression in papillomas. It has been suggested that tumors with high nuclear expression of p16 have better oncologic outcomes, such us a lower risk of death and recurrence in comparison with those with high cytoplasmic expression $(10,11,27)$. Due to the fact that $p 16$ is one of the major tumor suppressor genes, it is believed that the loss of its expression is one of the critical events in tumor progression $(20,27)$. It has also been proposed by some authors that the cytoplasmic localization of p16 expression could be the means of its inactivation and preventing its inhibitory function in the nucleus $(5,6)$. One of the possible explanations is that $\mathrm{p} 16$ binds to the cdk $4 / 6$ in the nucleus and then the complex is transferred to the cytoplasm $(5,6)$. Another explanation suggests that the cytoplasmic p16 expression may be due to the pl6 gene mutation in some tumors, which results to translocation of the defective protein to the cytoplasm (5, 28). The findings of this study have also revealed a statistically significant correlation between increased cytoplasmic expressions of p16 and tumor grade. These data indirectly support previous findings by Satgunaseelan et al. 
A
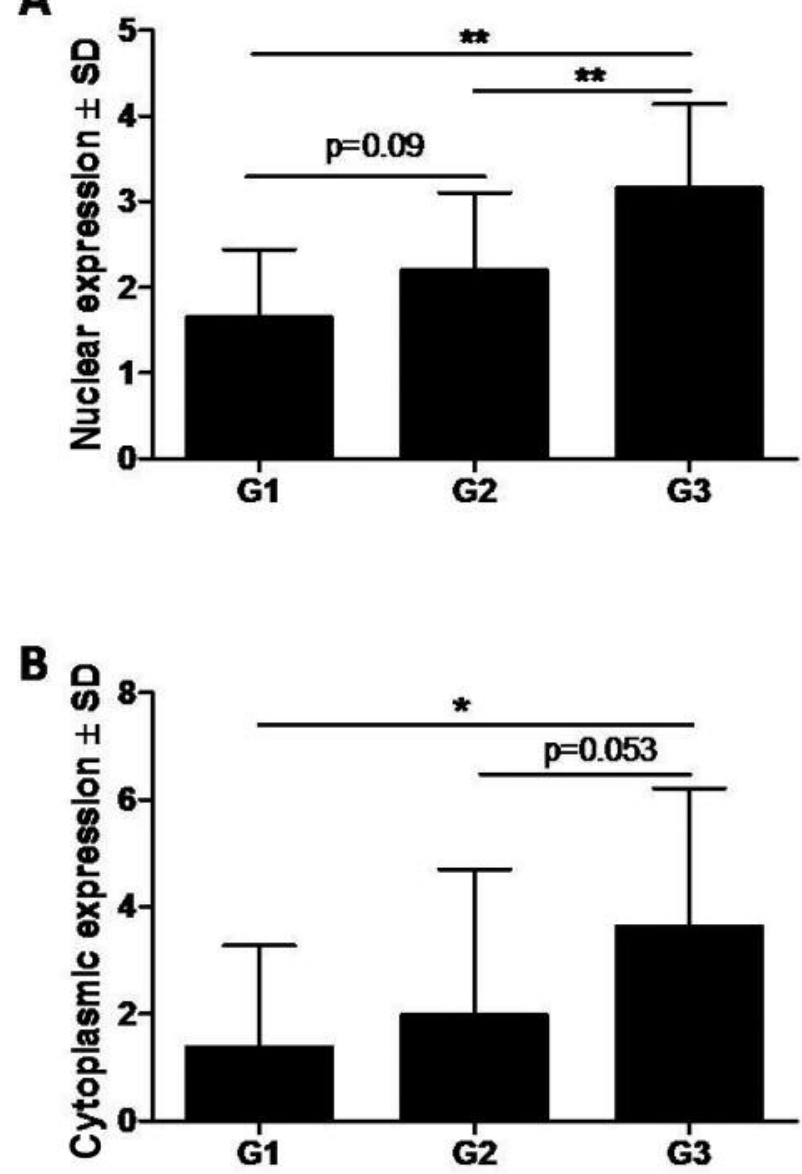

Figure 5. Nuclear expression of Ki-67 (A) and cytoplasmic expression of p16 (B) in cancer cells in regards to the tumor grade $(G)$. Data presented as mean \pm standard deviation $(S D), * p<0.05$, ** $p<0.01$. MannWhitney test.

(26), Dong et al. (29) and Isayeva et al. (30), who suggest that a stronger nuclear expression of p16 is correlated with less aggressive tumor behavior in oral squamous cell carcinomas. This study demonstrates that in larynx cancer cells, a lower expression of p16 in the nucleus and a stronger expression in the cytoplasm might be associated with tumor progression as a result of the loss of the preventive function of this protein in the nucleus.

The p27 protein is also a CDKI that inhibits the $\mathrm{CDK} /$ cyclin complex formation, which results in inhibition of $\mathrm{pRb}$ phosphorylation and cell cycle arrest at $\mathrm{G}_{1}$ phase $(8$, 15). Since CDKs and cyclins are necessary for cell cycle progression and the proliferation of the tumor cells, the level of expression of p27 in cancers is low, whereas in normal, quiescent cells the nuclear expression of the protein is detected by IHC $(15,31)$. It has been stated that the loss of p27 expression can be one of the mechanisms leading to

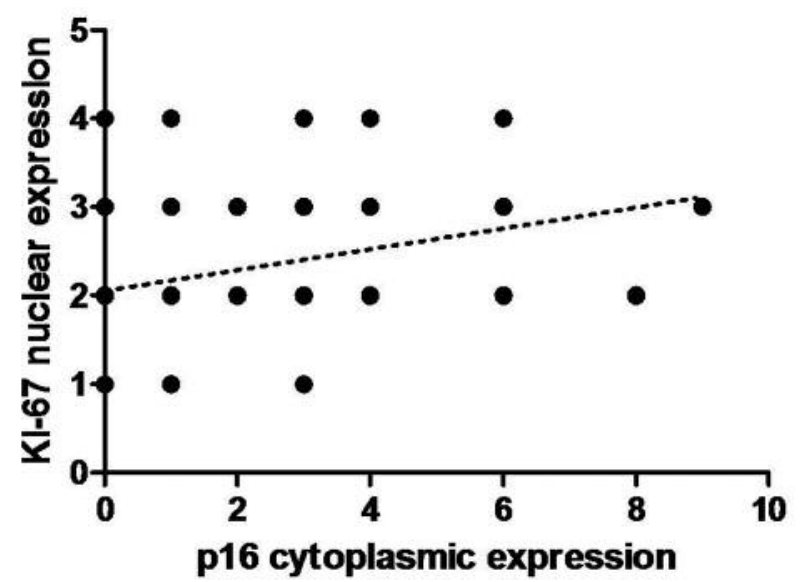

Figure 6. Medium positive correlation between the expression of cytoplasmic p16 and nuclear Ki-67 in cancer cells $(r=0.34, p<0.05$; Spearman correlation test). IRS: Immunoreactive Score.

tumor development and progression $(14,31,32)$. In many reports, alterations in the expression of $\mathrm{p} 27$ have been noticed (8, 13-15). Some researches of HNSCC have revealed decreased nuclear expression, of p27 which is comparable to our observations (2, 13-15). Furthermore, Fillies et al. (33), Kudo et al. (34) and Vallonthaiel et al. (15) also noticed decreased expression of p27 in tumor cells and they suggest that reduced expression of p27 occurs in the early stage of cancer development. Vallonthaiel et al. (15) also noticed that in normal epithelium adjacent to tumor, nuclear expression of p27 was observed, while decreased expression in the nucleus of tumor cells was observed. In this study we also noticed reduced nuclear expression of p27 in cancer cells, which was weaker in comparison to papilloma cells. However, in our study we detected significantly higher nuclear expression of p27 in laryngeal papillomas compared to LSCC.

In this study, a correlation between nuclear expression of p27 in cancer cells and the survival rate was not observed. Although many studies have revealed that the nuclear expression of p27 is often associated with good prognosis, there are also reports in which such correlation has not been found $(2,13,34,35)$. It has been suggested that a decreased p27 nuclear expression is associated with metastasis. It has also been stated that a low p27 expression or the lack of it may give cancer cells the possibility to grow because of altered extracellular matrix properties and modified cellular adhesion, which may lead to metastasis (31).

Ki-67 expression did not revealed any significant differences in LSCC compared to papillomas. However, we have observed a significant connection between the expression of Ki-67 in LSCC and tumor grade. Our findings can support the suggestions of other authors, i.e. that an increased Ki-67 
proliferation index in cancer cells could be an important indicator of tumor progression and aggressiveness $(8,36,37)$.

In conclusion, the nuclear expression of p16 and p27 was higher in LSCC than in laryngeal papillomas. Additionally, we also observed cytoplasmic expression of p16 in LSCC, which could support the hypothesis that the translocation of this protein to the cytoplasm results in the loss of its suppressive function in cell cycle progression. The results obtained may help in the better understanding of the processes leading to malignant transformation from benign lesions. There is a constant necessity for finding markers that could help predict the risk of malignant transformation. This study has confirmed that altered expression levels ofp16 and p27 proteins might be useful biomarkers in the progression of malignant LSCC.

\section{Acknowledgements}

The Authors thank MSc Agniezka Rusak from the Department of Histology and Embryology, Medical University in Wroclaw for her technical support.

\section{References}

1 Perez-Sayans M, Somoza-Martin JM, Barros-Angueira F, Reboiras-Lopez MD, Gandara Rey JM and Garcia-Garcia A: Genetic and molecular alterations associated with oral squamous cell cancer (review). Oncol Rep 22(6): 1277-1282, 2009.

2 MR De Almeida, Perez-Sayans M, Suarez-Penaranda JM, Somoza-Martin JM and Garcia-Garcia A: P27kip1 expression as a prognostic marker for squamous cell carcinoma of the head and neck. Oncol Lett 10(5): 2675-2682, 2015.

3 Manjarrez ME, Ocadiz R, Valle L, Pacheco C, Marroquin A, De la Torre C, Selman M and Gariglio P: Detection of human papillomavirus and relevant tumor suppressors and oncoproteins in laryngeal tumors. Clin Cancer Res 12(23): 6946-6951, 2006.

4 Bodnar M, Szylberg L, Kazmierczak W and Marszalek A: Immunohistochemical expression of p27(kip1) in metastatic laryngeal squamous cell carcinoma. Adv Med Sci 59(2): 206212, 2014.

5 Nilsson $\mathrm{K}$ and Landberg G: Subcellular localization, modification and protein complex formation of the cdk-inhibitor p16 in rb-functional and rb-inactivated tumor cells. Int J Cancer 118(5): 1120-1125, 2006.

6 Agarwal P, Lutful Kabir FM, De Innocentes P and Bird RC: Tumor suppressor Gene p16/INK4A/CDKN2A and its role in cell cycle exit, differentiation, and determination of cell fate, 2012. DOI: $10.5772 / 27882$

7 Sritippho T, Pongsiriwet S, Lertprasertsuke N, Buddhachat K, Sastraruji T and Iamaroon A: P16 - a possible surrogate marker for high-risk human papillomaviruses in oral cancer? Asian Pac J Cancer Prev 17(8): 4049-4057, 2016.

8 Zatonski T, Ciesielska U, Nowinska K, Ratajczak-Wielgomas K, Kobierzycki C, Pula B, Podhorska-Okolow M, Krecicki T and Dziegiel P: Expression of cell cycle-related proteins p16, p27, p53 and ki-67 in hpv-positive and -negative samples of papillomas of the upper respiratory tract. Anticancer Res 36(8): 3917-3924, 2016.
9 Pannone G, Rodolico V, Santoro A, Lo Muzio L, Franco R, Botti G, Aquino G, Pedicillo MC, Cagiano S, Campisi G, Rubini C, Papagerakis S, De Rosa G, Tornesello ML, Buonaguro FM, Staibano S and Bufo P: Evaluation of a combined triple method to detect causative hpv in oral and oropharyngeal squamous cell carcinomas: P16 immunohistochemistry, consensus per hpv-dna, and in situ hybridization. Infect Agent Cancer 7: 4, 2012.

10 Lai S, Wenaas AE, Sandulache VC, Hartman C, Chiao E, Kramer J and Zevallos JP: Prognostic significance of p16 cellular localization in oropharyngeal squamous cell carcinoma. Ann Clin Lab Sci 46(2): 132-139, 2016.

11 Zhao N, Ang MK, Yin XY, Patel MR, Fritchie K, Thorne L, Muldrew KL, Hayward MC, Sun W, Wilkerson MD, Chera BS, Hackman T, Zanation AM, Grilley-Olson JE, Couch ME, Shockley WW, Weissler MC, Shores CG, Funkhouser WK, Olshan AF and Hayes DN: Different cellular p16(ink4a) localisation may signal different survival outcomes in head and neck cancer. Br J Cancer 107(3): 482-490, 2012.

12 Grobe A, Hanken H, Kluwe L, Schollchen M, Tribius S, Pohlenz P, Clauditz T, Grob T, Simon R, Sauter G, Heiland M and Blessmann M: Immunohistochemical analysis of p16 expression, $\mathrm{hpv}$ infection and its prognostic utility in oral squamous cell carcinoma. J Oral Pathol Med 42(9): 676-681, 2013.

13 Vallonthaiel AG, Singh MK, Dinda AK, Kakkar A, Thakar A and Das SN: Prognostic significance of cytoplasmic p27 in oral squamous cell carcinoma. J Oral Pathol Med 45(7): 475-480, 2016.

14 Auerkari EI,Joewono V, Handjari DR, Sarwono AT, Suhartono AW, Eto K and Ikeda MA: Expression of p27kip1 and ecadherin in head and neck squamous cell carcinoma of indonesian patients. Open Dent J 8: 136-143, 2014.

15 Vallonthaiel AG, Singh MK, Dinda AK, Kakkar A, Thakar A and Das SN: Expression of cell cycle-associated proteins p53, prb, p16, p27, and correlation with survival: A comparative study on oral squamous cell carcinoma and verrucous carcinoma. Appl Immunohistochem Mol Morphol 24(3): 193-200, 2016.

16 Remmele W and Stegner HE: Recommendation for uniform definition of an immunoreactive score (irs) for immunohistochemical estrogen receptor detection (er-ica) in breast cancer tissue. Pathologe 8(3): 138-140, 1987.

17 Weiss D, Heinkele T and Rudack C: Reliable detection of human papillomavirus in recurrent laryngeal papillomatosis and associated carcinoma of archival tissue. J Med Virol 87(5): 860870, 2015.

18 Ganguly P and Ganguly N: Transcriptomic analyses of genes differentially expressed by high-risk and low-risk human papilloma virus e6 oncoproteins. Virusdisease 26(3): 105-116, 2015.

19 Chai RC, Lim Y, Frazer IH, Wan Y, Perry C, Jones L, Lambie D and Punyadeera C: A pilot study to compare the detection of hpv-16 biomarkers in salivary oral rinses with tumour p16(ink4a) expression in head and neck squamous cell carcinoma patients. BMC Cancer 16: 178, 2016.

20 Silva SD, Nonogaki S, Soares FA and Kowalski LP: P16 (ink4a) has clinicopathological and prognostic impact on oropharynx and larynx squamous cell carcinoma. Braz J Med Biol Res 45(12): 1327-1333, 2012.

21 Chou J, Lin YC, Kim J, You L, Xu Z, He B and Jablons DM: Nasopharyngeal carcinoma--review of the molecular mechanisms of tumorigenesis. Head Neck 30(7): 946-963, 2008. 
22 Konig F, Krekeler G, Honig JF, Cordon-Cardo C, Fischer G and Korabiowska M: Relation between human papillomavirus positivity and p16 expression in head and neck carcinomas - a tissue microarray study. Anticancer Res 27(1a): 283-288, 2007.

23 Lopez F, Alvarez-Marcos C, Alonso-Guervos M, Dominguez F, Suarez C, Hermsen MA and Llorente JL: From laryngeal epithelial precursor lesions to squamous carcinoma of the larynx: The role of cell cycle proteins and beta-catenin. Eur Arch Otorhinolaryngol 270(12): 3153-3162, 2013.

24 Prigge ES, Toth C, Dyckhoff G, Wagner S, Muller F, Wittekindt C, Freier K, Plinkert P, Hoffmann J, Vinokurova S, Klussmann JP, von Knebel Doeberitz M and Reuschenbach M: P16(ink4a) /Ki-67 co-expression specifically identifies transformed cells in the head and neck region. Int J Cancer 136(7): 1589-1599, 2015.

25 Szentkuti G, Danos K, Brauswetter D, Kiszner G, Krenacs T, Csako L, Repassy G and Tamas L: Correlations between prognosis and regional biomarker profiles in head and neck squamous cell carcinomas. Pathol Oncol Res 21(3): 643-650, 2015.

26 Satgunaseelan L, Virk SA, Lum T, Gao K, Clark JR and Gupta R: $\mathrm{P} 16$ expression independent of human papillomavirus is associated with lower stage and longer disease-free survival in oral cavity squamous cell carcinoma. Pathology 48(5): 441-448, 2016.

27 Perez-Sayans M, Suarez-Penaranda JM, Padin-Iruegas ME, Gayoso-Diz P, Reis-De Almeida M, Barros-Angueira F, Gandara-Vila P, Blanco-Carrion A and Garcia-Garcia A: The loss of p16 expression worsens the prognosis of OSCC. Appl Immunohistochem Mol Morphol 23(10): 724-732, 2015.

28 Ghiorzo P, Villaggio B, Sementa AR, Hansson J, Platz A, Nicolo G, Spina B, Canepa M, Palmer JM, Hayward NK and BianchiScarra G: Expression and localization of mutant p16 proteins in melanocytic lesions from familial melanoma patients. Hum Pathol 35(1): 25-33, 2004.

29 Dong Y, Wang J, Dong F, Wang X and Zhang Y: The correlations between alteration of p16 gene and clinicopathological factors and prognosis in squamous cell carcinomas of the buccal mucosa. J Oral Pathol Med 41(6): 463-469, 2012.

30 Isayeva T, Xu J, Ragin C, Dai Q, Cooper T, Carroll W, Dayan D, Vered M, Wenig B, Rosenthal E, Grizzle W, Anderson J, Willey CD, Yang ES and Brandwein-Gensler M: The protective effect of p16(ink4a) in oral cavity carcinomas: P16(ink4a) dampens tumor invasion-integrated analysis of expression and kinomics pathways. Mod Pathol 28(5): 631-653, 2015.
31 Pignataro L, Sambataro G, Pagani D and Pruneri G: Clinicoprognostic value of d-type cyclins and p27 in laryngeal cancer patients: A review. Acta Otorhinolaryngol Ital 25(2): 75-85, 2005.

32 Queiroz AB, Focchi G, Dobo C, Gomes TS, Ribeiro DA and Oshima CT: Expression of p27, p21(waf/cip1), and p16(ink4a) in normal oral epithelium, oral squamous papilloma, and oral squamous cell carcinoma. Anticancer Res 30(7): 2799-2803, 2010.

33 Fillies T, Woltering M, Brandt B, Van Diest JP, Werkmeister R, Joos $U$ and Buerger $\mathrm{H}$ : Cell cycle regulating proteins $\mathrm{p} 21$ and p27 in prognosis of oral squamous cell carcinomas. Oncol Rep 17(2): 355-359, 2007.

34 Kudo Y, Takata T, Ogawa I, Zhao M, Sato S, Takekoshi T, Miyauchi M and Nikai H: Reduced expression of p27(kip1) correlates with an early stage of cancer invasion in oral squamous cell carcinoma. Cancer Lett 151(2): 217-222, 2000.

35 Kapranos N, Stathopoulos GP, Manolopoulos L, Kokka E, Papadimitriou C, Bibas A, Yiotakis J and Adamopoulos G: P53, p21 and p27 protein expression in head and neck cancer and their prognostic value. Anticancer Res 21(1b): 521-528, 2001.

36 Nowinska K, Chmielewska M, Piotrowska A, Pula B, Pastuszewski W, Krecicki T, Podhorska-Okolow M, Zabel M and Dziegiel P: Correlation between levels of expression of minichromosome maintenance proteins, Ki-67 proliferation antigen and metallothionein in laryngeal squamous cell cancer. Int J Oncol 48(2): 635-645, 2016.

37 Wojnar A, Kobierzycki C, Krolicka A, Pula B, PodhorskaOkolow $\mathrm{M}$ and Dziegiel P: Correlation of ki-67 and mcm-2 proliferative marker expression with grade of histological malignancy $(\mathrm{G})$ in ductal breast cancers. Folia Histochem Cytobiol 48(3): 442-446, 2010.
Received March 4, 2017

Revised March 23, 2017

Accepted March 24, 2017 